\title{
Ultrastructure of Leptotrichia buccalis
}

\author{
By T. HOFSTAD AND K. A. SELVIG \\ Laboratory of Oral Microbiology, The Gade Institute, Schools of Medicine and \\ Dentistry, and Research Laboratories, School of Dentistry, \\ University of Bergen, Bergen, Norway
}

(Accepted for publication 22 November 1968)

SUMMARY

Thin sections of Leptotrichia buccalis were examined with the electron microscope. The organism showed a cell-wall profile characteristic of Gramnegative bacteria. A Gram-positive homofermentative Lactobacillus sp. was included in the study for comparison. The results indicate that $L$. buccalis should not be included within the Lactobacillaceae.

\section{INTRODUCTION}

The oral filamentous organism Leptotrichia buccalis was first adequately described by Thjötta, Hartman \& Böe (I939), who looked upon this organism as a species of Gram-negative bacteria related to the fusobacteria (Böe \& Thjötta, 1944). However, most later authors have been of the opinion that $L$. buccalis represents a species of Gram-positive bacteria related to the lactobacilli (Hamilton \& Zahler, I957; Gilmour, Howell \& Bibby, I96I).

A clear relationship exists between the Gram reaction and the structure of the bacterial cell wall. In the electron microscope the cell wall of Gram-positive bacteria appears as a thick homogenous layer close to the plasma membrane (Murray, I962). The cell wall of Gram-negative bacteria, on the other hand, is characterized by a varying number of thin electron-dense layers which follow more or less convoluted paths along the periphery of the cell (Murray, Steed \& Elson, 1965). In the present study, the morphology of L. buccalis and a homofermentative Lactobacillus sp. have been compared in the electron microscope, with particular attention to the cell-wall morphology of these micro-organisms.

\section{METHODS}

The isolation of Leptotrichia buccalis, strain L I I, has been described earlier (Hofstad, $1967 a)$. The bacteria were cultivated in nutrient broth enriched with $0.1 \%(\mathrm{w} / \mathrm{v})$ cysteine hydrochloride, $0.3 \%$ yeast extract (Difco), I \% glucose and $5 \%(\mathrm{v} / \mathrm{v})$ human ascitic fluid, and harvested by centrifugation when in the exponential phase of growth (I to 3 days at $37^{\circ}$ ). The homofermentative Lactobacillus sp. strain LA 6 was isolated from human saliva; it was cultivated in Bacto-Rogosa SL broth and the bacteria were harvested by centrifugation.

Pellets of intact organisms were suspended in acetate + veronal buffered osmium tetroxide fixative, transferred to agar, and embedded in polyester resin according to the procedure suggested by Kellenberger, Ryter \& Sèchaud (1958). Thin sections were 
cut with glass knives, collected on carbon-coated formvar membranes, and stained on a saturated solution of uranyl acetate in $50 \%(\mathrm{v} / \mathrm{v})$ ethanol in water for $60-90 \mathrm{~min}$. or on $2 \%$ aqueous phosphotungstic acid for $30 \mathrm{~min}$. The choice of contrasting material did not significantly influence the appearance of the structures of interest. Further reference to the staining technique has, consequently, been omitted. Specimens were examined in the electron microscope and photographed at plate magnifications of I0,000 to 30,000 diameters.

\section{RESULTS}

\section{Leptotrichia buccalis}

The organisms appeared in thin sections as circular or elongated structures; the length varied considerably depending on the plane of sectioning, while the diameter ranged from 0.6 to $0.8 \mu$. The concentric membranous structures surrounding the protoplasm will be referred to as outer membrane, solid membrane, and plasma membrane.

The outer membrane consisted of a double layer, about $70 \AA$ in width (Pl. I, fig. I, 2, 3). The solid membrane was seen as a single electron-dense line, about $50 \AA$ in width, following a straight-line course (P1. I, fig. I, 2, 3). The plasma membrane appeared as a doublet structure which, in general, closely followed the course of the solid membrane, separated from it by a $50 \AA$-wide space (Pl. I, fig. I, 2). The various membranous structures were, in general, closely adherent to each other. However, separations of the membranes occurred occasionally between the outer and the solid membrane, and between the solid and the plasma membrane (Pl. I, fig. 3). Invaginations of the plasma membrane, suggestive of mesosomes (Fitz-James, I960) were encountered in a few cases (Pl. I, fig. 3).

\section{The homofermentative Lactobacillus sp.}

The lactobacilli appeared elongated, with a diameter in transverse sections of $0.4-$ $0.5 \mu$. Pairs of cells attached end to end were frequently seen (Pl. 2, fig. 4). In contrast to Leptotrichia buccalis, only two separate structural entities, i.e. the cell wall and the plasma membrane, could be distinguished surrounding the cytoplasm. The cell wall appeared as a homogeneous or finely granular structure, 200-300 $\AA$ in width. Its inner and outer borders were in some cells diffusely outlined, in others more distinctly defined.

The cell wall was often separated from the underlying plasma membrane by a fine space (P1. 2, fig. 5). In most cells, however, the cell wall was closely adherent to the plasma membrane (Pl. 2, fig. 6). The external layer of the double-tracked plasma membrane was often more electron dense than the internal layer (Pl. 2, fig. 6).

Mesosomes were a prominent characteristic of this Lactobacillus sp. Most cells exhibited at least one such structure within each section (Pl. 2, fig. 4, 6). These formations did not affect the course of the cell wall. The cytoplasm was mostly composed of finely granular electron-dense material, while the centrally located nuclear regions displayed a less dense filamentous structure (P1. 2, fig. 4, 5). 
DISCUSSION

The cell wall profile of Leptotrichia buccalis is similar to that previously found in anaerobic Gram-negative organisms, such as Veillonella sp. (Bladen \& Mergenhagen, 1964) and Fusobacterium sp. (Tagaki \& Ueyama, 1963), and conforms to the general description of the Gram-negative cell-wall type (De Petris, 1965; Murray et al. 1965). Minor variations with respect to the appearance of the outer membrane, solid membrane, and plasma membrane, and the width of the spaces between these structures, are most likely related to the age of the organisms and the technique of specimen preparation. In contrast, the homofermentative Lactobacillus sp. examined here showed a cell wall profile typical of Gram-positive bacteria (Glauert, I962; Murray, 1962). With regard to cell wall structure, as well as other characteristics, the homofermentative Lactobacillus sp. closely resembles $L$. acidophilus as described by Reyn, Birch-Andersen \& Lapage (1966).

On the basis of observations of the cell-wall structure, therefore, Leptotrichia buccalis should be classified as a Gram-negative bacterium. This conclusion is in accordance with investigations on the chemical composition of its isolated cell walls (Hofstad, 1967b), which, in addition to mucopeptide, contained protein, lipid and polysaccharide. Araujo, Varah \& Mergenhagen (1963) and Gustafson, Kroeger \& Vaichulis (1966) have isolated endotoxins from $L$. buccalis by phenol + water extraction of whole organisms, further supporting the Gram-negative nature of this organism. Mesosomes are conspicuously present in aerobic Gram-positive bacteria (Salton, I967). However, mesosome-like configurations, similar to those found here in a few organisms of Leptotrichia buccalis, but apparently separated from the plasma membrane, have been observed in strains of Bacteroides sp. (Bladen \& Waters, 1963). The considerations above lead to the conclusion that $L$. buccalis should not be included within the Lactobacillaceae. The inclusion of the genus Leptotrichia in the Bacteroidaceae (Böe \& Thjötta, I944) seems more justified.

The electron microscopic work was carried out at the Institute of Anatomy, University of Bergen.

\section{REFERENCES}

Araujo, W. C. DE, Varah, E. \& Mergenhagen, S. E. (1963). Immunochemical analysis of human oral strains of Fusobacterium and Leptotrichia. J. Bact. 86, 837.

Bladen, H. A. \& Mergenhagen, S. E. (I964). Ultrastructure of Veillonella and morphological correlation of an outer membrane with particles associated with endotoxic activity. J. Bact. 88, 1482 .

Bladen, H. A. \& WATERS, J. F. (1963). Electron microscopic study of some strains of Bacteroides. J. Bact. 86, 1339.

BöE, J. \& Thü̈тTA Tн. (1944). The position of Fusobacterium and Leptotrichia in the bacteriological system. Acta path. microbiol. scand. 21, $44 \mathrm{I}$.

De PETRIS, S. (1965). Ultrastructure of the cell wall of E. coli. J. ultrastruct. Res. 12, 247.

Fitz-JAMEs, P. C. (1960). Participation of the cytoplasmic membrane in the growth and spore formation of bacilli. J. biophys. biochem. Cytol. 8, 507.

Gilmour, M. N., Howell, A. Jun. \& BibBy, B. G. (196I). The classification of organisms termed Leptotrichia (Leptothrix) buccalis. I. Review of the literature and proposed separation into Leptotrichia buccalis Trevisan, I879 and Bacterionema gen. nov., B. matruchotii (Mendel, 1919) comb. nov. Bact. Rev. 25, I3I.

GlaUert, A. M. (1962). The fine structure of bacteria. Br. med. Bull. 18, 245. 
Gustafson, K. L., Kroeger, A. V. \& Vaichulis, E. M. K. (1966). Chemical characteristics of Leptotrichia buccalis endotoxin. Nature, Lond. 212, 301.

HAMILTON, R. D. \& ZAHLER, S. A. (1957). A study of Leptotrichia buccalis. J. Bact. 73, 386.

HOFSTAD, T. (1967a). An anaerobic oral filamentous organism possibly related to Leptotrichia buccalis.

I. Morphology, some physiological and serological properties. Acta path. microbiol. scand. 69, 543 .

HoFSTAD, T. (1967 b). An anaerobic oral filamentous organism possibly related to Leptotrichia buccalis. II. Composition of cell walls. Acta path. microbiol. scand. 70, $46 \mathrm{I}$.

KeLlenBerger, E., RYTeR, A. \& SèchAUd, J. (1958). Electron microscopic study of DNA-containing plasms. II. Vegetative and mature phage DNA as compared with normal bacterial nucleoids in different physiological states. J. biophys. biochem. Cytol. 4, 671 .

MURRAY, R. G. E. (1962). Fine structure and taxonomy of bacteria. Symp. Soc. gen. Microbiol. 12, I 19.

Murray, R. G. E., Steed, P. \& Elson, H. E. (1965). The location of the mucopeptide in sections of the cell wall of Escherichia coli and other Gram-negative bacteria. Can.J. Microbiol. 11, 547.

Reyn, A., BirCh-ANDERsen, A. \& LAPAGE, S. P. (1966). An electron microscope study of thin sections of Haemophilus vaginalis (Gardner and Dukes) and some possibly related species. Can. J. Microbiol. 12, I125.

Salton, M. R. (1967). Structure and function of bacterial cell membranes. A. Rev. Microbiol. 2r, 417.

TAGAKI, A. \& UeYama, K. (1963). Characteristic cell wall structure of a Fusobacterium. Jap. $J$. Microbiol. 7, 43.

ThJötTA, TH., HARTMAN, O. \& BöE, J. (1939). A study of Leptotrichia Trevisan, history, morphology, biological and serological characteristics. Avh. norske VidenskAkad, Oslo. No. 5.

\section{EXPLANATION OF PLATES}

\section{Plate I}

Fig. I. Leptotrichia buccalis. The cytoplasm is surrounded by three concentric structures: doubletracked plasma membrane, solid membrane, and double-tracked, outer membrane. In this and the following figures, PM signifies plasma membrane, SM solid membrane, and OM outer membrane. Markers represent $0.1 \mu$. Magnification $\times 45,000$.

Fig. 2. L. buccalis. Cell wall structure of a longitudinally sectioned cell. The solid membrane appears as a single electron-dense line which pursues an almost straight-line course. $\times 100,000$.

Fig. 3. L. buccalis. Separations of the various cell-wall components have occurred in limited areas. A mesosome-like configuration (M) can be seen near the top of the illustration. $\times 100,000$.

\section{Plate 2}

Fig. 4. Homofermentative Lactobacillus sp. The organisms appear as rods, often adhering end to end in pairs. The cell wall (CW) forms a thick, homogenous or granular layer immediately outside the plasma membrane. $\mathrm{M}$ mesosome, $\mathrm{N}$ nuclear region. $\times 100,000$.

Fig. 5. Homofermentative Lactobacillus sp. Longitudinally sectioned cell shows separations between cell wall and plasma membrane. $N$ nuclear region. $\times 100,000$.

Fig. 6. Homofermentative Lactobacillus sp. Cross-sectioned cells with cell wall tightly adherent to the plasma membrane, except in area near lower edge of illustration. The outer layer of the plasma membrane is more electron dense than the inner layer. M mesosome. $\times 100,000$. 

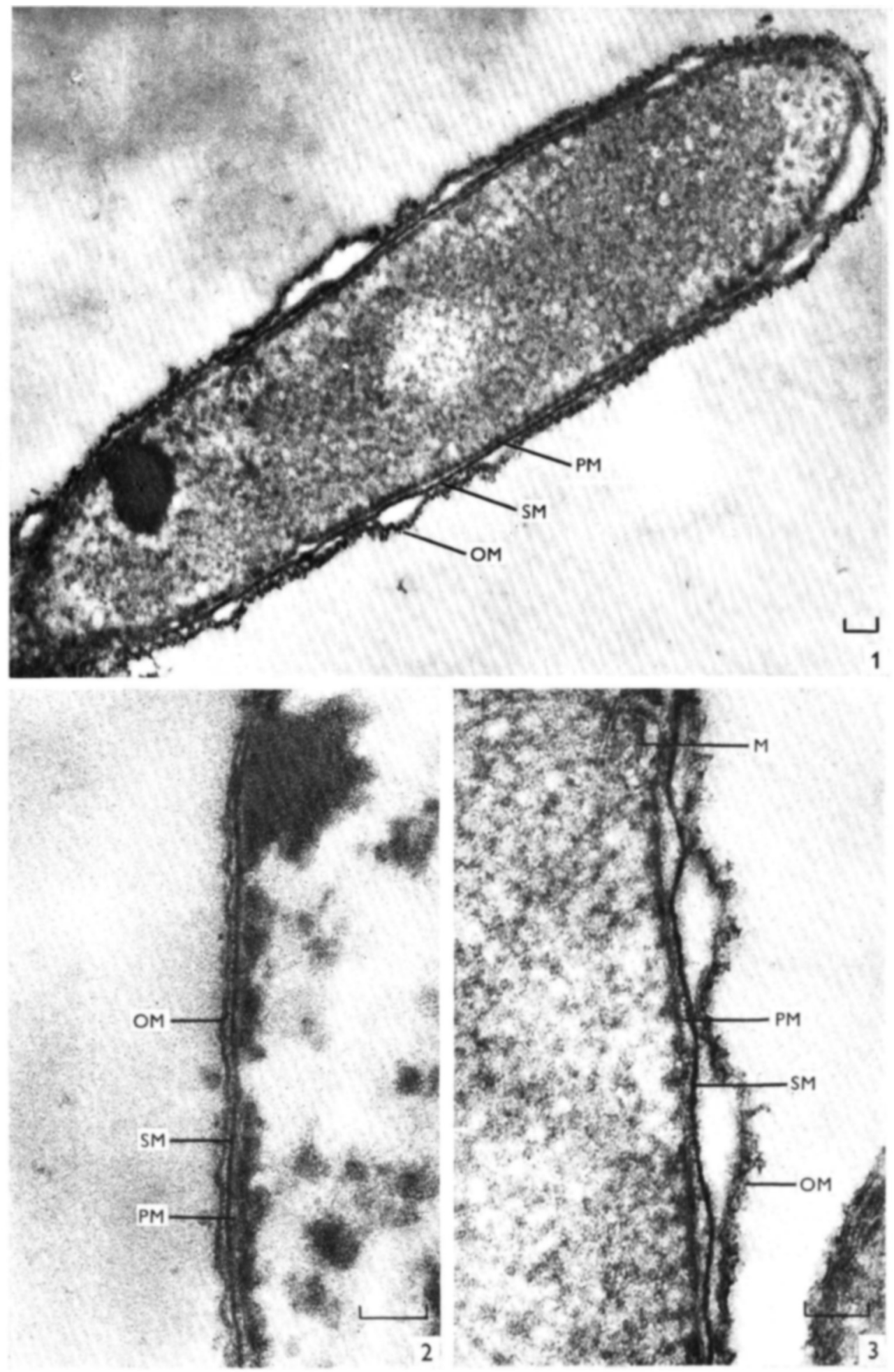

T. HOFSTAD AND K. A. SELVIG

(Facing p. 26) 
Journal of General Microbiology, Vol. 56, No. I

Plate 2
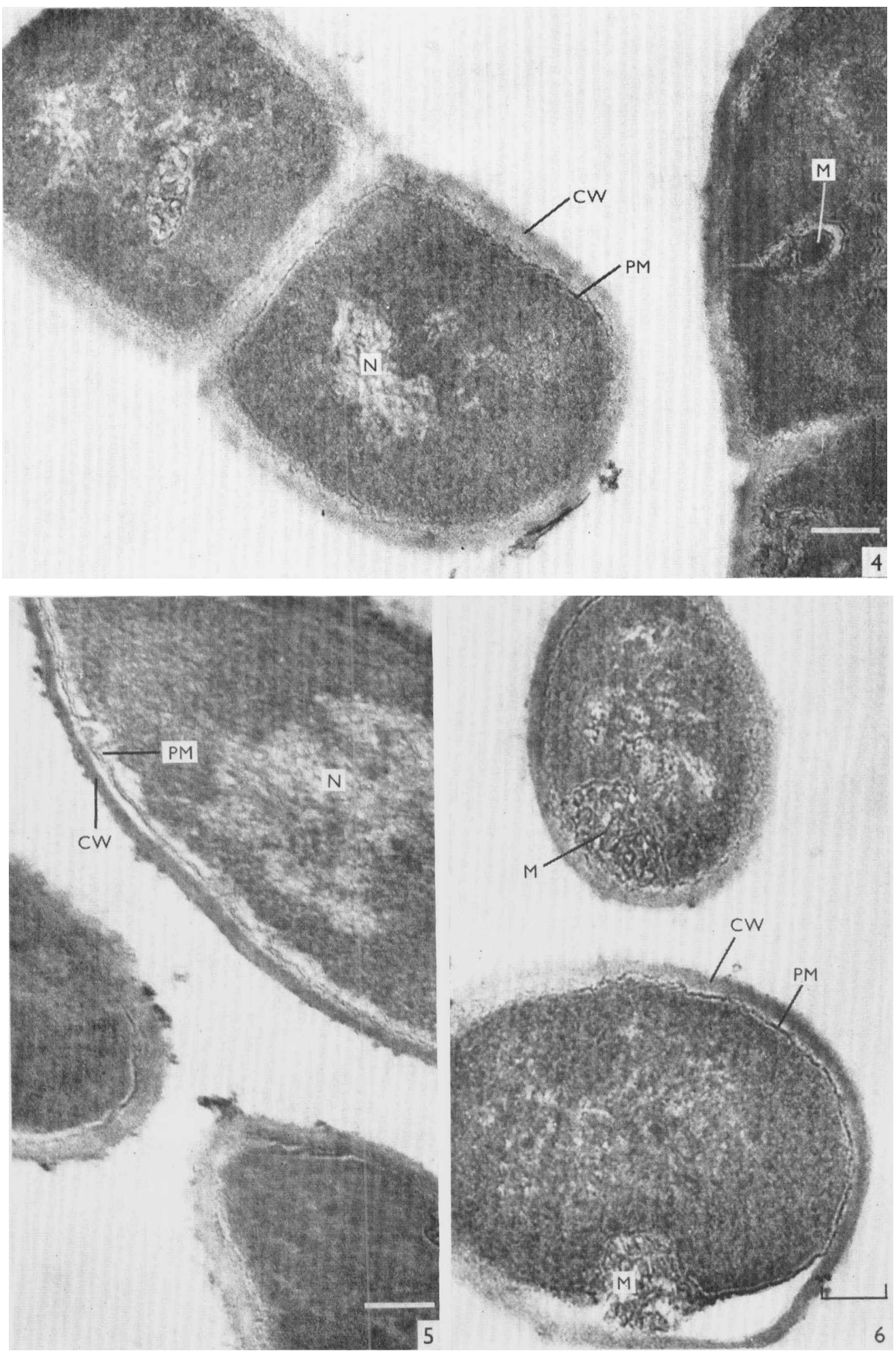

T. HOFSTAD AND K. A. SELVIG 